\title{
Synthesis, characterization, and application of silica supported ionic liquid as catalyst for reductive amination of cyclohexanone with formic acid and triethyl amine as hydrogen source
}

\author{
Ashif H. Tamboli, Avinash A. Chaugule, Faheem A. Sheikh, Wook-Jin Chung, Hern Kim* \\ Department of Energy Science and Technology, Energy and Environment Fusion Technology Center, Myongji University, Yongin, Kyonggi-do 449-728, \\ Republic of Korea
}

\section{A R T I C L E I N F O}

Article history:

Received 24 February 2014

Accepted 26 March 2015

Published 20 August 2015

Keywords:

Supported ionic liquid phase

Catalyst

Reductive amination

Cyclohexanone

Ionic liquids

\begin{abstract}
A B S T R A C T
A silica supported ionic liquid was synthesized and characterized by scanning electron microscopy (SEM), Fourier transform infrared spectroscopy, X-ray diffraction, $\mathrm{N}_{2}$ adsorption-desorption, and thermogravimetric analysis. All these techniques, especially SEM results indicated the presence of well-defined spherical particles having diameters larger than the pristine silica particles, confirming the successful immobilization of the ionic liquid. The prepared silica supported ionic liquid was used in the reductive amination of cyclohexanone under different conditions with different azeotropic mixtures of formic acid and triethyl amine as a hydrogen source. The catalyst showed efficient catalytic performance and excellent yields of $\mathrm{N}$-cyclohexyl amine derivatives in the range of $58 \%$ to $84 \%$ at $30{ }^{\circ} \mathrm{C}$. After completion of the reaction, the catalyst was easily recovered by simple filtration and reused for another five cycles without any significant impact on product yields. The obtained catalytic performance indicates that the present catalyst is green, very active, and reusable for the reductive amination of cyclohexanone.
\end{abstract}

(C) 2015, Dalian Institute of Chemical Physics, Chinese Academy of Sciences. Published by Elsevier B.V. All rights reserved.

\section{Introduction}

Ionic liquids (ILs) have been considered as an efficient alternative to volatile organic compounds (VOCs) for "green processing" because of their nonvolatility, nonflammablity, and high thermal stability [1-3]. Therefore, ILs have emerged as an active area of research for modern catalytic systems. The potential of ILs as catalysts for several chemical transformations has already been established. Moreover, ILs have been used as solvents in various biphasic IL-transition metal-catalyzed organic reactions to improve catalyst recycling and/or reusability [4-6]. In recent years, many researchers have given considerable attention to the immobilization of ILs, known as supported
ILs (SILs), using various organic [7,8] and inorganic supports $[9,10]$ to improve the applicability of IL-based catalytic processes at an industrial level. Among the various forms of SIL systems, the supported ionic liquid phase (SILP) system is a very easy and effective catalyst system. In SILP systems, an ILfilm is immobilized on a high-surface area porous solid (e.g., silica) and the homogeneous catalyst can easily be dissolved in the IL layer [11,12]. The resulting solid combines the advantages of a heterogeneous catalyst with the active species being soluble in the IL phase and behaving as a homogeneous catalyst [13-16]. Furthermore, this SILP catalysis system incorporates the most attractive features of homogeneous catalysis, such as high activity and selectivity, with the useful quali-

\footnotetext{
* Corresponding author. Tel: +82-31-3306688; Fax: +82-31-3366336; E-mail: hernkim@mju.ac.kr This work was supported by the National Research Foundation of Korea (NRF)-Grants funded by the Ministry of Science, ICT and Future Planning (2014R1A2A2A01004352) and the Ministry of Education (2009-0093816), Republic of Korea. 
ties of heterogeneous catalysts such as large surface area, easy product separation, high stability, and high reusability [17-19]. In this way, the SILP catalyst system reduces the differences between traditional homogeneous and heterogeneous catalysis systems. The search for efficient, convenient, and recyclable catalytic systems based on SILP to overcome the deficiencies in existing systems is one of the most fundamental but challenging problems in catalysis.

The wide range of applications for amines in the pharmaceutical and fine chemical industries has caused intense research into the development of efficient methods to produce these compounds in high yield and purity, considered important goals in organic synthesis [20-22]. One of the most widespread reaction types for this purpose, as well as for effective $\mathrm{C}-\mathrm{N}$ bond forming, is the catalytic reductive amination of carbonyl compounds [23-25]. This approach involves two steps, the condensation of a ketone with a corresponding amine and subsequent imine hydrogenation using formic acid:triethyl amine as the $\mathrm{H}_{2}$ donor (Scheme 1).

During past decades, the chemical modification of this reaction has evolved from the reductive amination of aldehyde and ketones. Previous reports on this reaction have focused on the use of transition metal catalysts [26-30], organocatalysts [31-35], and ILs [36] as the initiating species with reducing agents ranging from metal hydrides to $\mathrm{H}_{2}$ gas [37-40]. The combination of formic acid and formaldehyde methylation of amines, known as the Eschweiler-Clarke reaction [41,42], is a method of wide synthetic use and has been the subject of critical investigation [43] in which a series of substituted benzylamines were used as model compounds. However, hydrogen donation from an azeotropic mixture of formic acid and triethyl amine was not exploited in these works [37-43]. To the best of our knowledge, the use of hydrogen donation from an azeotropic mixture of formic acid and triethyl amine for direct reductive amination reactions has not yet been explored. The atom economy and cleanliness of reductive amination makes it the most important catalytic method in synthetic organic chemistry. In an effort to develop a mild and efficient procedure for the reductive amination of carbonyl compounds, we have focused our attention towards the fabrication of an IL catalyst system. Imao et al. [44] first reported such a use of ILs, where 1-butyl-3- methyl imidazolium tetrafluoroborate [(BMIm) $\left.\mathrm{BF}_{4}\right]$ was used as the reaction medium for the direct reductive amination of carbonyl compounds with hydrogen catalyzed by an iridium complex.

In this study, we synthesized a SILP catalyst and applied it to a reductive amination reaction. The hydrogen donor source used here was an azeotropic mixture of formic acid and triethyl amine and the reaction was carried out at room temperature. In this way, the use of gaseous hydrogen and pressure reactors could be avoided, which rendered the reaction safer and easier

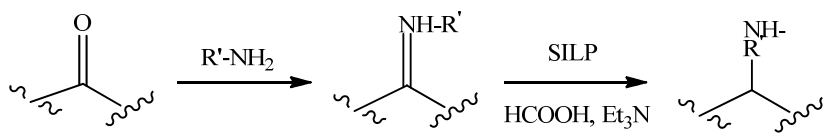

R'- $\mathrm{H}, \mathrm{CH}_{3}, \mathrm{Ph}$

Scheme 1. Reductive amination of ketones. to perform. Furthermore, we described a variety of possible modifications of this particular catalytic system, such as eco-friendly usage of ILs, immobilization on solid supports, and use of other simple chemicals as the hydrogen source.

\section{Experimental}

\subsection{General}

Methyl imidazole (99.0\%), 1-chloroacetic acid (99.0\%), cyclohexanone (99.0\%), $\mathrm{Na}_{2} \mathrm{CO}_{3}$ (99.0\% IR grade), $\mathrm{Na}_{2} \mathrm{SO}_{4}(99.0 \%$ IR grade) and all amine derivatives listed in Tables 2 and 4 were purchased from Sigma-Aldrich. All the solvents used in the reactions were purchased from commercial sources and distilled from the relevant agents prior to use. Ultrapure water (double distilled water purified with a Milli-Q system) was used to prepare aqueous solutions. Suitable absorptive capacity, flow ability, low cost, high stability, and high reusability are important considerations for catalyst supports used in heterogeneous catalyst systems. Therefore, we selected amorphous silica as the supporting material for the immobilization of the prepared ILs.

\subsection{Preparation}

\subsubsection{Preparation of $\left[\mathrm{Cmmim}^{+}\right]\left[\mathrm{Cl}^{-}\right]$}

The IL 3-(carboxymethyl)-1-methyl-1H-imidazol-3-ium chloride $\left(\left[\mathrm{Cmmim}^{+}\right]\left[\mathrm{Cl}^{-}\right]\right)$was synthesized according to a previously reported procedure [45]. In brief, monochloro acetic acid (6.73 g, 0.10mol) and 1-methylimidazole (8.21 g, $0.10 \mathrm{~mol})$ were added to a round-bottom flask containing $50 \mathrm{~mL}$ of acetonitrile and fitted with a reflux condenser. The resulting mixture was heated for $24 \mathrm{~h}$ at $80^{\circ} \mathrm{C}$ with continuous stirring. After completion of the reaction, the excess solvents were evaporated under reduced pressure and the obtained product was washed with diethyl ether ( $30 \mathrm{~mL})$ and dried under vacuum for $24 \mathrm{~h}$, resulting in a slightly yellow colored liquid product (yield: 90\%).

${ }^{1} \mathrm{H}$ NMR (400 MHz, $\left.\mathrm{D}_{2} \mathrm{O}, 25^{\circ} \mathrm{C}\right): \delta 3.92(\mathrm{~s}, 3 \mathrm{H}), 5.07(\mathrm{~s}, 2 \mathrm{H})$, 7.49 (s, 1H), 7.50 (s, 1H), $8.77(\mathrm{~s}, 1 \mathrm{H}) ;{ }^{13} \mathrm{C}$ NMR (125 MHz, $\mathrm{D}_{2} \mathrm{O}$, $25{ }^{\circ} \mathrm{C}$ ): $\delta 47.2,53.3,126.4,141.2,172.9$; FTIR: 3404, 3111, 3092, 2964, 2852, 1710, 1637, 1581, 1454, 1177, 1078, 758 $\mathrm{cm}^{-1}$.

\subsubsection{Preparation of $\left[\mathrm{Cmmim}^{+}\right]\left[\mathrm{Tf}_{2} \mathrm{~N}^{-}\right]$}

A solution of $4 \mathrm{~g}$ of bis(trifluoromethane)sulfonamide lithium salt in $12 \mathrm{~mL}$ of acetonitrile and $2 \mathrm{~g}$ of $\left[\mathrm{Cmmim}^{+}\right]\left[\mathrm{Cl}^{-}\right]$were mixed in a $50-\mathrm{mL}$ round bottom flask to synthesize (carboxymethyl)-1-methyl-1H-imidazol-3-ium-bis((trifluoromethyl) sulfonyl)amide $\left(\left[\mathrm{Cmmim}^{+}\right]\left[\mathrm{Tf}_{2} \mathrm{~N}^{-}\right]\right)$. After stirring for $1 \mathrm{~h}$ at room temperature, the resulting slightly yellow viscous liquid was filtered and dried in a vacuum oven for $24 \mathrm{~h}$ (yield: 85\%).

${ }^{1} \mathrm{H}$ NMR (400 MHz, $\left.\mathrm{D}_{2} \mathrm{O}, 25^{\circ} \mathrm{C}\right): \delta 3.92(\mathrm{~s}, 3 \mathrm{H}), 5.07(\mathrm{~s}, 2 \mathrm{H})$, 7.50 (s, 1H), 7.51 (s, 1H), 8.77 (s, 1H); ${ }^{13} \mathrm{C}$ NMR (125 MHz, $\mathrm{D}_{2} \mathrm{O}$, $\left.25^{\circ} \mathrm{C}\right): \delta 40.1,47.2,53.3,61.8,126.3,126.4,141.2,172.9$; FTIR : 3404, 3111, 3092, 2964, 2852, 1710, 1637, 1581, 1454, 1177, $1078,971,834.5,758.4,648.4 \mathrm{~cm}^{-1}$. 


\subsubsection{Immobilization of $\left[\mathrm{Cmmim}^{+}\right]\left[\mathrm{Tf}_{2} \mathrm{~N}^{-}\right]$ILs on silica}

The $\left[\mathrm{Cmmim}^{+}\right]\left[\mathrm{Tf}_{2} \mathrm{~N}^{-}\right](2 \mathrm{~g})$ and silica powder (10 g) (pore size $15 \mathrm{~nm}$, pore volume $1.15 \mathrm{~cm}^{3} / \mathrm{g}$, and surface area $\sim 300$ $\mathrm{m}^{2} / \mathrm{g}$ ) were carefully added to $10 \mathrm{~mL}$ of methanol in round bottom flask. After stirring of the mixture for $90 \mathrm{~min}$, the methanol was evaporated in vacuum to leave a dry light yellow colored powder. The sample was rinsed with diethyl ether to remove excess IL, and then dried in a vacuum oven for $24 \mathrm{~h}$.

\subsection{Characterization}

The obtained catalyst was characterized with Fourier transform infrared spectroscopy (FTIR; Varian 2000), ${ }^{1} \mathrm{H}$ and ${ }^{13} \mathrm{C}$ NMR spectroscopy (Bruker Avance-400), powder X-ray diffraction (PXRD; Rigaku Miniflex, Rigaku Corporation, Japan) and BET surface area measurements (BELSORP-Max [MP], BEL Japan, Inc). The surface morphology of the catalyst was studied by scanning electron microscopy (SEM) using a Hitachi S-3500N instrument.

\subsection{Typical procedure for reductive amination of cyclohexanone}

Cyclohexanone (0.02 mol), the chosen amine (0.02 mol) and the corresponding solvent were added to a $25-\mathrm{mL}$ round bottom flask fitted with a reflux condenser. The reaction mixture was stirred at $30^{\circ} \mathrm{C}$ for $15-20 \mathrm{~min}$ followed by the addition of $10 \mathrm{~mol} \%$ SILP catalyst. Then, $0.5396 \mathrm{~mL}$ of formic acid:triethyl amine mixture (5:2) was added to the reaction mixture as a proton source and the reaction mixture was stirred for the required time period (Tables 2 and 4). After completion of the reaction, the solid from the reaction solution was separated by simple filtration and subsequently reused for the next cycle. The excess solvent in the reaction solution was evaporated using reduced pressure and the reaction mixture was extracted with diethyl ether. The combined extracts were dried over anhydrous $\mathrm{Na}_{2} \mathrm{SO}_{4}$ and evaporated. The products were isolated based on pure single spot on a thin layer chromatograph (TLC). Further, the product was purified by column chromatography using $10 \%$ EtOAc in hexene as the eluent to obtain the pure amine.

Synthesis of $\mathrm{N}$-cyclohexyl-benzyl amine derivatives. $\mathrm{H}^{1} \mathrm{NMR}$ (400 MHz, $\left.\mathrm{CDCl}_{3}, 25^{\circ} \mathrm{C}\right): \delta 1.22-1.92(\mathrm{~m}, 10 \mathrm{H}), 2.47-2.58(\mathrm{~m}$, 1H), $2.07(\mathrm{~m}, 1 \mathrm{H}), 3.02(\mathrm{~s}, 2 \mathrm{H}), 7.22-7.31(\mathrm{~m}, 5 \mathrm{H}) .{ }^{13} \mathrm{C}$ NMR (125 MHz, $\mathrm{D}_{2} \mathrm{O}, 25{ }^{\circ} \mathrm{C}$ ): $\delta 26.0,34.7,52.6,59.1,129.0,129.5$, 141.2, 146.3; FTIR: 3320, 3061, 3022, 2916, 2848, 1681, 1604, $1551,1353,1116,879,728,705,604 \mathrm{~cm}^{-1}$.

Synthesis of 4-nitro- $N$-cyclohexylaniline derivatives. $\mathrm{H}^{1}$ NMR (400 MHz, $\left.\mathrm{CDCl}_{3}, 25^{\circ} \mathrm{C}\right): \delta 1.16-1.81(\mathrm{~m}, 10 \mathrm{H}), 2.02(\mathrm{~m}$, $1 \mathrm{H}), 3.37-3.55(\mathrm{~m}, 1 \mathrm{H}), 6.74\left(\mathrm{~d}, J=7.3, \mathrm{H}_{\mathrm{Ar}}\right), 7.95(\mathrm{~d}, J=7.2$, $\mathrm{H}_{\mathrm{Ar}}$ ), ${ }^{13} \mathrm{C}$ NMR (125 MHz, $\left.\mathrm{D}_{2} \mathrm{O}, 25{ }^{\circ} \mathrm{C}\right): \delta 145.1,128.2,118.5$, 109.2, 50.4, 28.3, 25.0; FTIR: 3376, 2957, 2846, 1633, 1560, $1385,1321,1117,772,747,691 \mathrm{~cm}^{-1}$.

Synthesis of 4-chloro-N-cyclohexylaniline derivatives. $\mathrm{H}^{1}$ $\operatorname{NMR}\left(400 \mathrm{MHz}, \mathrm{CDCl}_{3}, 25^{\circ} \mathrm{C}\right): \delta 7.18\left(\mathrm{~d}, J=7.2, \mathrm{H}_{\mathrm{Ar}}\right), 6.97(\mathrm{~d}, J=$ 7.3, $\mathrm{H}_{\mathrm{Ar}}$ ), 2.06-2.12 (m. 1H), $2.24(\mathrm{t}, 1 \mathrm{H}), 0.98-1.67$ (m, $\left.10 \mathrm{H}\right)$; ${ }^{13} \mathrm{C}$ NMR (125 MHz, $\left.\mathrm{D}_{2} \mathrm{O}, 25{ }^{\circ} \mathrm{C}\right): 148.4,131.2,112.8,107.1$,
55.3, 37.5,27.8, 23.1; FTIR: 3376, 2957, 2846, 1633, 1520, $1353,1117,772,747,691 \mathrm{~cm}^{-1}$.

Synthesis of $N$-cyclohexylaniline derivatives. $\mathrm{H}^{1}$ NMR (400 $\left.\mathrm{MHz}, \mathrm{CDCl}_{3}, 25^{\circ} \mathrm{C}\right): \delta 1.08-1.90(\mathrm{~m}, 10 \mathrm{H}), 2.01(\mathrm{~m}, 1 \mathrm{H}), 3.21(\mathrm{t}$, $1 \mathrm{H}), 7.08-7.20(\mathrm{~m}, 5 \mathrm{H}) .{ }^{13} \mathrm{C}$ NMR $\left(125 \mathrm{MHz}, \mathrm{D}_{2} \mathrm{O}, 25^{\circ} \mathrm{C}\right): \delta 26.0$, 34.7, 52.6, 59.1, 129.0, 129.5, 141.2, 146.3; FTIR: 3296, 2938, 2853, 1644, 1530, 1351, 1201, 747, $623 \mathrm{~cm}^{-1}$.

Synthesis of 4-hydroxy- $N$-cyclohexylaniline derivatives. $\mathrm{H}^{1}$ NMR (400 MHz, $\left.\mathrm{CDCl}_{3}, 25{ }^{\circ} \mathrm{C}\right): \delta 1.17-1.90(\mathrm{~m}, 10 \mathrm{H}), 2.01(\mathrm{~m}$, $1 \mathrm{H}), 3.21$ (s, $1 \mathrm{H}), 7.08-7.21(\mathrm{~m}, 5 \mathrm{H}) .{ }^{13} \mathrm{C}$ NMR (125 MHz, $\mathrm{D}_{2} \mathrm{O}$, $25{ }^{\circ} \mathrm{C}$ ): $\delta$ 26.1, 49.6, 129.0, 129.4, 144.8; FTIR: 3308, 2940, 2853, 1644, 1353, 1201, $751 \mathrm{~cm}^{-1}$.

Synthesis of $N$-ethylaniline. $\mathrm{H}^{1} \mathrm{NMR}\left(400 \mathrm{MHz}, \mathrm{CDCl}_{3}, 25\right.$ $\left.{ }^{\circ} \mathrm{C}\right): \delta 1.29(\mathrm{t}, 3 \mathrm{H}), 3.48(\mathrm{~m}, 2 \mathrm{H}), 4.07(\mathrm{~s}, 1 \mathrm{H}), 6.77-7.26(\mathrm{~m}, 5 \mathrm{H})$. ${ }^{13} \mathrm{C}$ NMR (125 MHz, $\left.\mathrm{D}_{2} \mathrm{O}, 25{ }^{\circ} \mathrm{C}\right): \delta 14.8,36.7,114.1,120.2$, 129.5, 147.3; FTIR: 3433, 3121, 2898, 1651, 1531, $728 \mathrm{~cm}^{-1}$.

Synthesis of $N$-methyl-1-phenylethanamine. $\mathrm{H}^{1} \mathrm{NMR}(400$ $\left.\mathrm{MHz}, \mathrm{CDCl}_{3}, 25^{\circ} \mathrm{C}\right): \delta 1.20(\mathrm{~d}, 3 \mathrm{H}), 2.01(\mathrm{~s}, 1 \mathrm{H}), 3.22(\mathrm{~s}, 3 \mathrm{H}), 4.08$ (m, 1H), 7.27-7.40 (m, 5H). ${ }^{13} \mathrm{C}$ NMR (125 MHz, $\left.\mathrm{D}_{2} \mathrm{O}, 25^{\circ} \mathrm{C}\right): \delta$ 22.4, 34.7, 65.3, 127, 127.8, 144.9; FTIR: 3394, 3098, 2947, 2852, 1644, 1530, 847, $765 \mathrm{~cm}^{-1}$.

Synthesis of $\mathrm{N}$-(pyridin-4-ylmethyl)aniline. $\mathrm{H}^{1}$ NMR (400 $\left.\mathrm{MHz}, \mathrm{CDCl}_{3}, 25^{\circ} \mathrm{C}\right): \delta 4.0(\mathrm{~s}, 1 \mathrm{H}), 4.29(\mathrm{~s}, 3 \mathrm{H}), 3.22(\mathrm{~s}, 3 \mathrm{H}), 4.08$ $(\mathrm{m}, 1 \mathrm{H}), 6.84-7.38(\mathrm{~m}, 7 \mathrm{H}), 8.59(\mathrm{~d}, J=6.77, \mathrm{HPy}),{ }^{13} \mathrm{C}$ NMR $(125$ $\left.\mathrm{MHz}, \mathrm{D}_{2} \mathrm{O}, 25^{\circ} \mathrm{C}\right): \delta 51.2,114.2,119.9,130.1,123.8,147.9$; FTIR: $3405,3394,3070,3029,2992,2924,2894,2868,1667$, $1606,1553,1211,994,802 \mathrm{~cm}^{-1}$.

\section{Results and discussion}

\subsection{Characterization of silica-supported ionic liquid catalysts}

The morphology and structure of the SILP powder were investigated using SEM. As shown in Fig. 1, it clearly shows the presence of polydisperse SILP particles with spherical shape. The pristine silica particles were small and agglomerated. However, the SILP particles were well-defined and had distinct size owing to the immobilization of the IL. This change of the parent structure of the silica to well defined particles in SILP catalyst indicated that $\left[\mathrm{Cmmim}^{+}\right]\left[\mathrm{Tf}_{2} \mathrm{~N}^{-}\right]$had been immobilized on the surface of the silica particles.

The FTIR spectra of silica, the SILP catalyst, and the IL are presented in Fig. 2. It demonstrates that changes in functional groups occurred upon immobilization of $\left[\mathrm{Cmmim}^{+}\right]\left[\mathrm{Tf}_{2} \mathrm{~N}^{-}\right]$on the pure silica. The prepared SILP catalyst showed IR bands at frequencies close to those of the pristine silica particles. For the

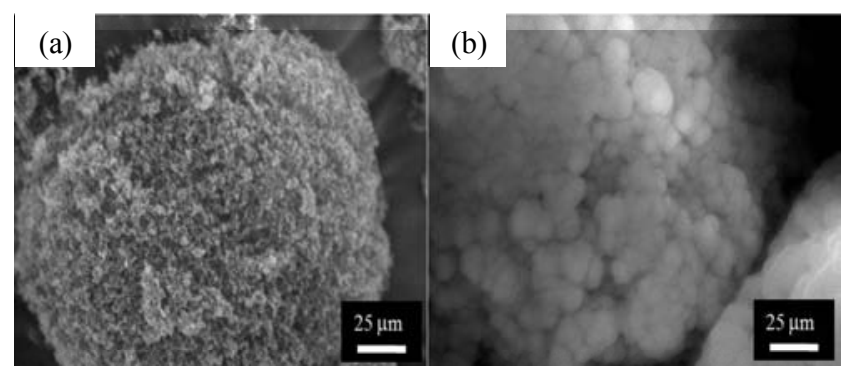

Fig. 1. SEM images of silica particles before (a) and after (b) immobilization of the IL. 


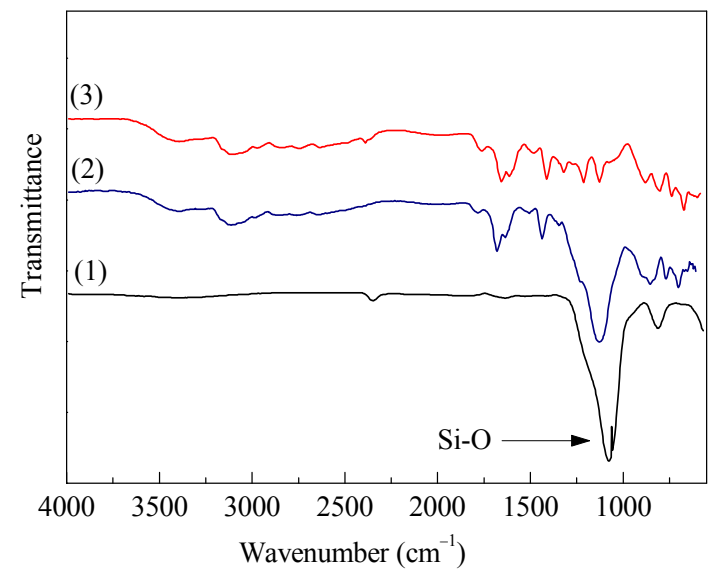

Fig. 2. FTIR spectra of the silica particles (1), SILP catalyst (2), and IL (3).

silica, the band at $1073 \mathrm{~cm}^{-1}$ represents $\mathrm{Si}-0$ bonds, while the bands positioned at 3410 and $1633 \mathrm{~cm}^{-1}$ correspond to the stretching and bending vibrations of $\mathrm{Si}-\mathrm{OH}$, respectively. The FTIR spectrum of $\left[\mathrm{Cmmim}^{+}\right]\left[\mathrm{Tf}_{2} \mathrm{~N}^{-}\right]$showed the characteristic bands of ILs at $3273 \mathrm{~cm}^{-1}$ for acidic $\mathrm{O}-\mathrm{H}$ and while the bands at 3148 and $3073 \mathrm{~cm}^{-1}$ correspond to $\mathrm{C}-\mathrm{H}$ stretching vibrations of the imidazolium ring. The relatively weaker bands occurring at 2970, 2921, and $2880 \mathrm{~cm}^{-1}$ are the stretching vibrations of $\mathrm{CH}_{3}$ and $\mathrm{CH}_{2}$, while the bands at 1463 and $1381 \mathrm{~cm}^{-1}$ correspond to their respective bending vibrations. All of the above mentioned IR bands were found in the SILP catalyst, confirming the immobilization of the IL on the surface of the silica. Furthermore, these results confirm that bonding existed between the silica and the IL.

TG analysis was employed to investigate the thermal stability of the chemically modified silica; the observed weight loss was associated with the loss of the organic components attached to the surface (Fig. 3). In the case of the pristine silica, $96.4 \%$ of its residual weight remained at $700{ }^{\circ} \mathrm{C}$. For the SILP, an initial weight loss of $3.6 \%$ occurred until $84{ }^{\circ} \mathrm{C}$ owing to the loss of surface silanol groups and the adsorbed moisture in the silica. The complete loss of the attached organic moieties occurred at $200{ }^{\circ} \mathrm{C}$. The amount of organic moieties was deter-

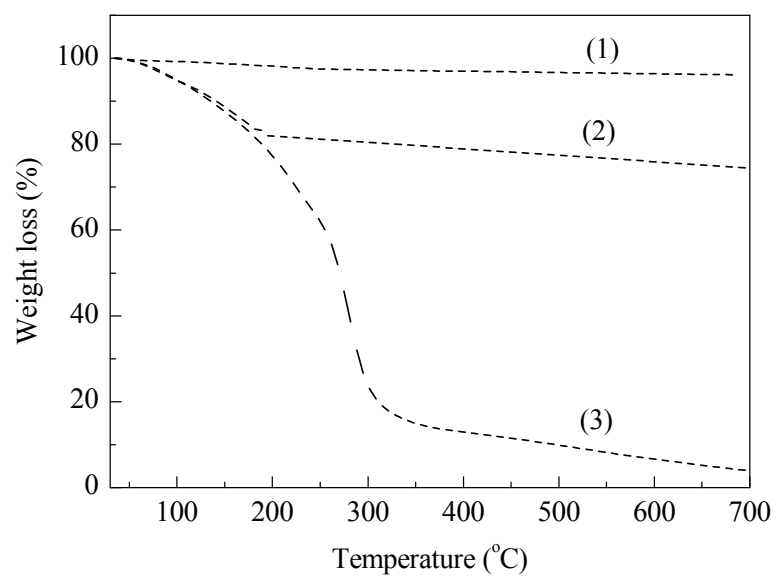

Fig. 3. TG analyses of silica particles (1), SILP catalyst (2), and IL (3).

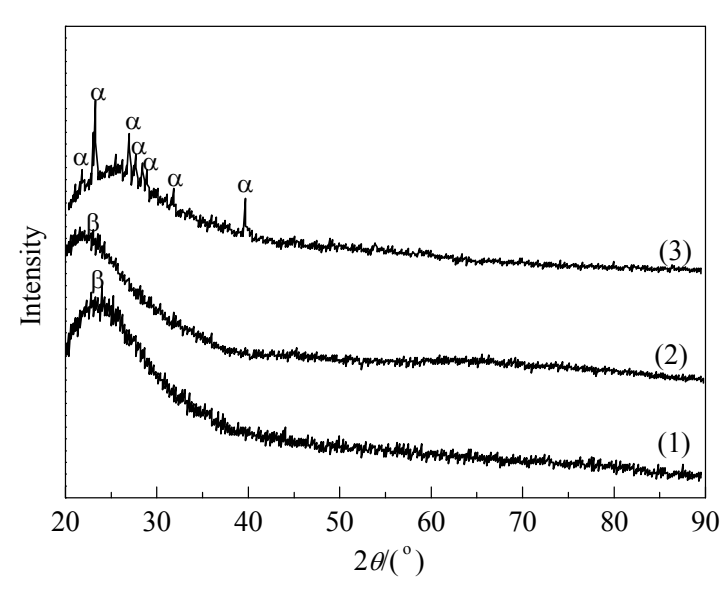

Fig. 4. XRD patterns of silica (1), SILP catalyst (2), and IL (3).

mined to be about $27.22 \%$ that of the solid support. In case of the IL, the complete loss of all organic structure was observed around $230{ }^{\circ} \mathrm{C}$. The slope observed from $235{ }^{\circ} \mathrm{C}$ onwards may have been caused by the decomposition of alkyl-carboxylic acid groups of the IL. From these results, a simple conclusion can be drawn that immobilization of the IL on the silica particles in the SILP increased its thermal stability compared with that of the pure IL.

Fig. 4 shows the XRD patterns of the pristine silica particles, SILP, and $\left[\mathrm{Cmmim}^{+}\right]\left[\mathrm{Tf}_{2} \mathrm{~N}\right]$, respectively. The silica consisted of a broad diffraction peak at $2 \theta=23.65^{\circ}$, whereas that of $\left[\mathrm{Cmmim}^{+}\right]\left[\mathrm{Tf}_{2} \mathrm{~N}^{-}\right]$displayed relatively a sharp peaks at $2 \theta=$ $22.93^{\circ}, 25.78^{\circ}, 26.50^{\circ}, 27.21^{\circ}, 29.01^{\circ}$, and $39.85^{\circ}$. The broad peak in the SILP catalyst was caused by $\mathrm{SiO}_{2}$ and was similar to that observed for the pristine silica. This demonstrates that the structures of the $\left[\mathrm{Cmmim}^{+}\right]\left[\mathrm{Tf}_{2} \mathrm{~N}^{-}\right]$and the mode of interaction between the two were different from that of the blended hybrid system.

$\mathrm{N}_{2}$ adsorption-desorption analyses of the silica and SILP catalyst were performed to shed light on the adsorption of IL onto the pristine silica particles. As shown in Table 1, the BET surface area, pore volume, and pore diameter of the pristine silica were $267.77 \mathrm{~m}^{2} / \mathrm{g}, 1.778 \mathrm{~cm}^{3} / \mathrm{g}$, and $16.66 \mathrm{~nm}$, compared with $196.02 \mathrm{~m}^{2} / \mathrm{g}, 0.947 \mathrm{~cm}^{3} / \mathrm{g}$, and $6.71 \mathrm{~nm}$, respectively, for the SILP catalyst. Thus, it is clear that the SILP exhibited decreased values compared with those of the pristine silica particles. The reason for this can be traced to the high surface to volume ratio of the pristine silica particles, which were smaller in size than the particles covered in immobilized IL (i.e., the SILP catalyst system) as indicated in Fig. 1.

\subsection{Catalytic activity of SILP for reductive amination}

The performance of the SILP as a heterogeneous catalyst

Table 1

Textural properties of silica and SILP catalyst.

\begin{tabular}{lccc}
\hline Sample & $\begin{array}{c}\text { BET surface area } \\
\left(\mathrm{m}^{2} / \mathrm{g}\right)\end{array}$ & $\begin{array}{c}\text { Pore volume } \\
\left(\mathrm{cm}^{3} / \mathrm{g}\right)\end{array}$ & $\begin{array}{c}\text { Pore diameter } \\
(\mathrm{nm})\end{array}$ \\
\hline Silica & 267.77 & 1.778 & 16.66 \\
SILP catalyst & 196.02 & 0.947 & 6.71 \\
\hline
\end{tabular}


was tested using the direct reductive amination reaction of cyclohexanone (Scheme 2). Table 2 lists the syntheses of different $\mathrm{N}$-cyclohexyl derivatives using a variety of amines carried out under different conditions. Reductive amination did not proceed well at a suitable rate in the presence of unsupported IL catalyst (Table 2, entry 1 ), and neither the pristine silica (Table 2, entry 11). From the preliminary experiments it was found that the reductive amination of cyclohexanone proceeded smoothly with SILP catalyst. It should be noted that the catalyst exhibited excellent activity for all amines screened. Thus, the present catalytic method is useful for the reductive amination of cyclic ketones to the corresponding amines. The obtained yields were $58 \%, 84 \%, 78 \%, 80 \%, 64 \%, 73 \%$, and $84 \%$ for Entries 2, 3, 4, 5, 6, and 7, respectively. Benzyl amine was found to easily react with cyclohexanone using the SILP catalyst at $40{ }^{\circ} \mathrm{C}$, giving around an $84 \%$ yield of $\mathrm{N}$-cyclohexyl-benzyl amine in $5 \mathrm{~h}$ (Table 2, entry 3).

To further explore the activity of the SILP catalyst, some other carbonyl compounds for reductive amination. The product yields of the selected acetaldehyde, acetophenone, and iso-nicotinaldehyde with the respective amines were $78 \%$, $70 \%$, and $68 \%$, respectively (Table 2 , entries $8-10$ ). The reductive amination of cyclohexanone with the SILP was best affected with a $5: 2$ formic acid:triethylamine azeotropic mixture in acetonitrile solvent at $40^{\circ} \mathrm{C}$ with $10 \mathrm{wt} \%$ catalyst in $5 \mathrm{~h}$ reaction time (Table 2, entry 3). The presence of the electron-donating group in benzyl amine and its non-bulky structure means that the amine group could easily condense with the carbonyl carbon of the cyclohexanone ring. Thus, the combination of these substrates constitutes a model reaction for evaluating the efficiency of a catalyst. Hence, cyclohexanone was treated with benzyl amine under various conditions in further studies.

Inspired by this fact, we then tried to explore the reaction of benzyl amine and cyclohexanone in a variety of solvents using the SILP catalyst under standard reaction conditions. In the cases of reaction in methanol, DMSO, and acetonitrile, complete reaction was obtained within 5 h with $74 \%, 81 \%$, and $84 \%$ yield, respectively (Table 3 , entries 1,3 , and 5). Therefore, acetonitrile was selected for parametric study experiments.

To optimize the reaction conditions, reactions with the test amine substrate and solvent (benzyl amine and acetonitrile) were carried out at different temperature (Table 4), formic acid:triethyl amine ratio, and catalyst loading. The effect of temperature on the reductive amination reaction of benzyl amine and cyclohexanone was investigated at 30,40 , and $50^{\circ} \mathrm{C}$. The reaction was found to proceed at a faster rate at 30 and 40 ${ }^{\circ} \mathrm{C}$, yielding a maximum yield of $84 \%$ of $\mathrm{N}$-cyclohexyl-benzyl amine within the minimum time of $5 \mathrm{~h}$ (Table 4 , entries 1,2).

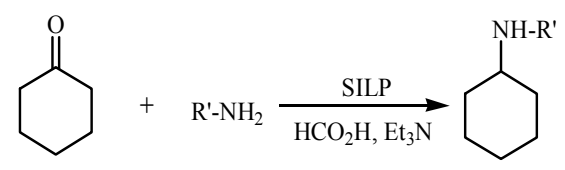

$$
\mathrm{R}-\mathrm{H}, \mathrm{CH}_{3}, \mathrm{Ph}
$$

Scheme 2. Synthesis of amine derivatives of cyclohexanone using SILP catalyst system.
Table 2

Synthesis of amine derivatives of cyclohexanone using SILP catalyst.

Entry $\quad$ Ketone $\quad$ Amine $\begin{gathered}\text { Isolated } \\ \text { yield (\%) }\end{gathered}$

2<smiles>O=C1CCCCC1</smiles>

3

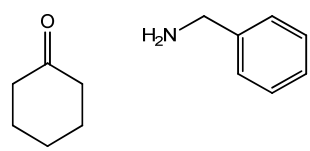

4<smiles>O=C1CCCCC1</smiles><smiles>Nc1ccc([N+](=O)[O-])cc1</smiles>

5<smiles>Nc1ccccc1</smiles>

6<smiles>O=C1CCCCC1</smiles><smiles>Nc1ccc(O)cc1</smiles>

7<smiles>O=C1CCCCC1</smiles><smiles>Nc1ccc(Cl)cc1</smiles>

8

$\mathrm{CH}_{3} \mathrm{CHO}$<smiles>Nc1ccccc1</smiles>

9<smiles>CC(=O)c1ccccc1</smiles>

10<smiles>O=Cc1ccncc1</smiles><smiles>Nc1ccccc1</smiles>

11
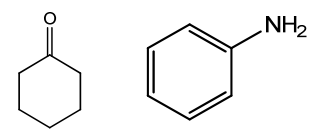

58<smiles>NC1CCCCC1</smiles>

84<smiles>c1ccc(CNC2CCCCC2)cc1</smiles>

78<smiles>O=[N+]([O-])c1ccc(NC2CCCCC2)cc1</smiles>

80<smiles>c1ccc(NC2CCCCC2)cc1</smiles>

64<smiles>Oc1ccc(NC2CCCCC2)cc1</smiles>

73<smiles>Clc1ccc(NC2CCCCC2)cc1</smiles>

78<smiles>CCNc1ccccc1</smiles>

70<smiles>CNC(C)c1ccccc1</smiles>

68
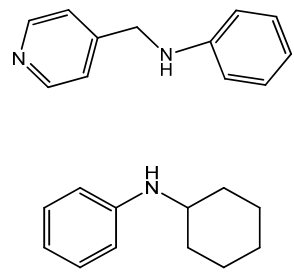

Reaction conditions: substrate $0.02 \mathrm{~mol}$, SILP catalyst $10 \mathrm{wt} \%$, acetonitrile $30 \mathrm{~mL}, 5: 2$ FA-TEA $0.5 \mathrm{~mL}, 40^{\circ} \mathrm{C}, 5 \mathrm{~h}$. All products were characterized by ${ }^{1} \mathrm{H},{ }^{13} \mathrm{C}$ NMR, and FTIR.

However, the yield of amine product slightly decreased to $78 \%$ at $50{ }^{\circ} \mathrm{C}$. Thus, the optimal reaction temperature was $30{ }^{\circ} \mathrm{C}$. The effect of SILP catalyst loading was investigated (Table 4, entries 4-6). When the catalyst amount was increased from 5 to 10 wt $\%$, the product yield increased from $57 \%$ to $84 \%$. However, further increase in the amount of catalyst to $20 \mathrm{wt} \%$ resulted in a decreased yield of $78 \%$. Increasing the catalyst amount also 
Table 3

Solvent screening for reductive amination reactions of cyclohexanone.

\begin{tabular}{lccc}
\hline Entry & Solvent & Time (h) & Isolated yield (\%) \\
\hline 1 & Methanol & 5 & 74 \\
2 & Chloroform & 10 & 68 \\
3 & DMSO & 5 & 81 \\
4 & DCM & 8 & 73 \\
5 & Acetonitrile & 5 & 84 \\
\hline
\end{tabular}

Reaction conditions: cyclohexanone $0.02 \mathrm{~mol}$, benzyl amine $0.02 \mathrm{~mol}$, 5:2 FA-TEA $0.5 \mathrm{~mL}$, solvent $30 \mathrm{~mL}, 40^{\circ} \mathrm{C}$.

Table 4

Parametric study of reductive amination reaction of cyclohexanone.

\begin{tabular}{lccccc}
\hline $\begin{array}{l}\text { En- } \\
\text { try }\end{array}$ & $\begin{array}{c}\text { Catalyst } \\
\text { (wt\%) }\end{array}$ & HCOOH:Et ${ }_{3}$ ratio & $\begin{array}{c}\text { Tempera- } \\
\text { ture }\left({ }^{\circ} \mathrm{C}\right)\end{array}$ & $\begin{array}{c}\text { Time } \\
(\mathrm{h})\end{array}$ & $\begin{array}{c}\text { Isolated yield } \\
(\%)\end{array}$ \\
\hline 1 & 10 & $5: 2$ & 30 & 5 & 84 \\
2 & 10 & $5: 2$ & 40 & 5 & 84 \\
3 & 10 & $5: 2$ & 50 & 6.5 & 78 \\
4 & 5 & $5: 2$ & 30 & 5 & 57 \\
5 & 10 & $5: 2$ & 30 & 5 & 84 \\
6 & 20 & $5: 2$ & 30 & 5 & 78 \\
7 & 10 & $5: 1$ & 30 & 5 & - \\
8 & 10 & $5: 2$ & 30 & 5 & 84 \\
9 & 10 & $5: 5$ & 30 & 5 & - \\
\hline
\end{tabular}

Unless otherwise noted, reaction was run using cyclohexanone $(0.02$ $\mathrm{mol})$ and benzyl amine $(0.02 \mathrm{~mol})$.

reduced the reaction rate, but the reaction yield was unchanged. To determine the role of the proton source in the formation of the amines in the second step, a series of reactions were performed in which the ratio of $\mathrm{HCOOH}$ and $\mathrm{Et}_{3} \mathrm{~N}$ was changed from 5:1 to 5:2 and 5:5 at constant temperature (Table 4, entries 7-9). The results indicated that yield of amine product decreased with $\mathrm{HCOOH}$ and $\mathrm{Et}_{3} \mathrm{~N}$ ratio from 5:2 to 5:1, and nearly no amine product was isolated when the ratio was increased to 5:5.

The above results indicated that the immobilization of an IL on silica was an effective strategy to fabricate an ideal catalyst system for the reductive amination of cyclohexanone. The present combination of IL and silica shows that an active and durable catalyst system is possible. This approach may find potential applications in other SILP catalyzed reaction systems, and our results serve to solidify the utility of SILP catalysts in reductive amination reactions. Results obtained with different catalysts and reducing agents or hydrogen source in the reported literature is presented in Table 5 for comparison.

Table 5

Results obtained with different hydrogen sources in selected literature and our work.

\begin{tabular}{|c|c|c|c|}
\hline Catalyst & $\begin{array}{l}\text { Reducing } \\
\text { agent }\end{array}$ & $\begin{array}{c}\text { Operating } \\
\text { Conditions }\end{array}$ & $\begin{array}{l}\text { Yield (\%) } \\
\text { /Ref. }\end{array}$ \\
\hline$\left[\operatorname{Ir}(\operatorname{cod})_{2}\right] \mathrm{BF}_{4}$ & $\mathrm{H}_{2}$ & $\begin{array}{l}\mathrm{H}_{2} \text { pressure }\left(50 \mathrm{~kg} / \mathrm{m}^{2}\right) \text {, } \\
0.5 \mathrm{~h}, \mathrm{MeOH} \text {, room temp. }\end{array}$ & $94 /[44]$ \\
\hline $\mathrm{Ru}\left(\mathrm{Cl}_{3}\right)$ & $\mathrm{CO}$ & $\begin{array}{l}\text { Pressure } 10 \text { bar, } 24 \mathrm{~h} \text {, } \\
\text { MeCN, room temp. }\end{array}$ & $89 /[46]$ \\
\hline $\mathrm{Pd} / \mathrm{C}$ & $\mathrm{Et}_{3} \mathrm{SiH}$ & $30 \mathrm{~min}$, room temp. & $94 /[47]$ \\
\hline $\mathrm{Pd} / \mathrm{C}$ & $\mathrm{HCOO}^{-} \mathrm{NH}_{3}{ }^{+}$ & $40 \mathrm{~min}$, room temp. & $96 /[48]$ \\
\hline SILP & HCOOH/TEA & $5 \mathrm{~h}, \mathrm{MeCN}$, room temp. & $84 /$ this work \\
\hline
\end{tabular}

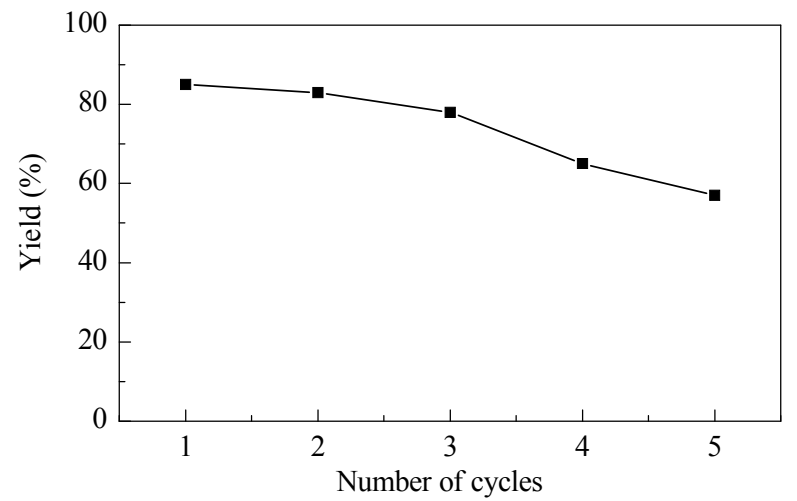

Fig. 5. Reusability of the supported ionic liquid phase catalyst system.

\subsection{Catalyst reusability}

The reusability of the SILP catalyst was also studied, and the results are summarized in Fig. 5. It was found that the catalyst could be conveniently recovered at the end of reaction, and could be readily reused for the next cycle. The use of recycled SILP catalyst without any regeneration steps for subsequent reductive amination reactions of cyclohexanone was investigated. As shown in Fig. 5, there was slight decrease in amine product yield after three consecutive cycles. This reduced product yield can be attributed to the exhaustion of the IL underneath the core silica supported ionic liquid particles.

\section{Conclusions}

A supported IL phase catalyst was efficiently prepared and used in the reductive amination of cyclohexanone by a variety of amines under mild reaction conditions with formic acid and triethyl amine as the hydrogen source. Characterization results indicated that the IL was efficiently bound to the silica particles. The yields for the reductive amination reaction were remarkably excellent, in the range of $58 \%$ to $85 \%$. Various solvents were screened for reductive amination of cyclohexanone by benzyl amine to determine the best solvent for this reaction. The effect of the reaction conditions on the reductive amination of cyclohexanone was also investigated by screening parameters including the substrate/catalyst ratio and formic acid/triethyl amine ratio. The catalyst could also be sufficiently recovered and reused for three runs without loss of activity. This catalytic system is environmentally green and we believe that the present study will aid in the research of catalytic reductive amination processes.

\section{References}

[1] Pfruender H, Midjojo M, Kragl U, Weuster-Botz D. Angew Chem Int $E d t, 2004,43: 4529$

[2] Neves C M S S, Freire M G, Coutinho J A P. RSC Adv, 2012, 2: 10882

[3] DeSimone J M. Science, 2002, 297: 799

[4] Welton T, Coord Chem Rev, 2004, 248: 2459

[5] Liu W, Holladay J. Catal Today, 2013, 200:106

[6] Anastas P, Eghbali N. Chem Soc Rev, 2010, 39: 301 


\section{Graphical Abstract}

\section{Chin. J. Catal., 2015, 36: 1365-1371 doi: 10.1016/S1872-2067(15)60848-8 \\ Synthesis, characterization, and application of silica supported ionic liquid as catalyst for reductive amination of cyclohexanone with as hydrogen source}

Ashif H. Tamboli, Avinash A. Chaugule, Faheem A. Sheikh, Wook-Jin Chung, Hern Kim*

Myongji University, Korea

A silica supported ionic liquid phase (SILP) was synthesized, and it showed excellent catalytic performance for the reductive amination of cyclohexanone. The catalytic activity of SILP is due to the synergistic effect of ILs and silica, the SILP activate the imine substrate to reduce by taking hydrogen from formic acid and triethyl amine which leads to amine product.

[7] Han L, Choi H J, Kim D K, Park S W, Liu B, Park D W. J Mol Catal A, 2011, 338: 58

[8] Sans V, Gelat F, Karbass N, Burguete M I, Garcia-Verdugo E. Luis S V, Adv Synth Catal, 2010, 352: 3013

[9] Mehnert C P. Chem Eur J, 2004, 11: 50

[10] Werner S, Szesni N, Bittermann A, Schneider M J, Harter P, Haumann M, Wasserscheid P. Appl Catal A, 2010, 377: 70

[11] Ochsner E, Schneider M J, Meyer C, Haumann M, Wasserscheid P. Appl Catal A, 2011, 399: 35

[12] Li H , Bhadury P S, Song B, Yang S. RSC Adv, 2012, 2: 12525

[13] Riisager A, Wasserscheid P, van Hal R, Fehrmann R. J Catal, 2003, 219: 452

[14] Wasserscheid P.J Ind Eng Chem, 2007, 13: 325

[15] Podolean I, Hardacre C, Goodrich P, Brun N, Backov R, Coman S M, Parvulescu V I. Catal Today, 2013, 200: 63

[16] Haumann M, Riisager A. Chem Rev, 2008, 108: 1474

[17] Werner S, Szesni N, Fischer R W, Haumann M, Wasserscheid P. Phys Chem Chem Phys, 2009, 11: 10817

[18] Gu Y L, Li G X. Adv Synth Catal, 2009, 351: 817

[19] Mehnert C P. Chem Eur J, 2005, 11: 50

[20] Tallman K R, Grandy D K. Neuropsychopharm, 2012, 37: 2553

[21] Tarasevich V A, Kozlov N G. Russ Chem Rev, 1999, 64: 55

[22] Xu Z W, Yan P F, Xu W J, Jia S Y, Xia Z, Chung B, Zhang Z C. RSC Adv, 2014, 4: 59083

[23] Li C, Villa-Marcos B, Xiao J. J Am Chem Soc, 2009, 131: 6967

[24] Domine M E, Hernandez-Soto M C, Navarro M T, Perez Y.Catal Today, 2011, 172: 13

[25] Williams G D, Pike R A, Wade C E, Wills M. Org Lett, 2003, 5: 4227

[26] Alcock N J, Mann I, Peach P, Wills M. Tetrahedron: Asymm, 2002, 13: 2485

[27] Gladiali S, Alberico E. Chem Soc Rev, 2006, 35: 226

[28] Xie J H, Zhu S F, Zhou Q L. Chem Rev, 2011, 111: 1713

[29] Uematsu N, Fujii A, Hashiguchi S, Ikariya T, Noyori R. J Am Chem
Soc, 1996, 118: 4916

[30] Mao J, Baker D C. Org Lett, 1999, 1: 841

[31] Abdur-Rashid K, Lough A J, Morris R H. Organometallics, 2001, 20: 1047

[32] Shirai S, Nara H, Kayaki Y, Ikariya T. Organometallics, 2009, 28: 802

[33] Hou G H, Tao R, Sun Y K, Zhang X M, Gosselin F. J Am Chem Soc, 2010, 132: 2124

[34] Surya Prakash G K, Do C, Mathew T, Olah G A. Catal Lett, 2010, 137: 111

[35] Apodaca R, Xiao W. Org Lett, 2001, 3: 1745

[36] Drinkel E E, Campedelli R R, Manfredi A M, Fiedler H D, Nome F. J Org Chem, 2014, 79: 2574

[37] Reddy P S, Kanjilal S, Sunitha S, Prasad R B N. Tetrahedron Lett, 2007, 48: 8807

[38] Schellenberg K A. J Org Chem, 1963, 28: 3259

[39] Brown H C, Kanth J V B, Dalvi P V, Zaidlewicz M. J Org Chem, 1999, 64: 6263

[40] Matsumura T, Nakada M. Tetrahedron Lett, 2014, 55: 1829

[41] Eschweiler W. Ber Deut Chem Gesell, 1905, 38: 880

[42] Clarke H T, Gillespie H B, Weisshaus S Z. J Am Chem Soc, 1933, 55:4571

[43] Pine S H, Sanchez B L.J Org Chem, 1971, 36: 829

[44] Imao D, Fujihara S, Yamamoto T, Ohta T, Ito Y. Tetrahedron, 2005, 61: 6988

[45] Fei Z, Zhao D, Geldbach T J, Scopelliti R, Dyson P J. Chem Eur J, 2004, 10: 4886

[46] Kolesnikov P N, Yagafarov N Z, Usanov D L, Maleev V I, Chusov D. Org Lett, 2015, 17:173

[47] Mirza-Aghayan M, Tavana M M, Rahimifard M, Boukherroub R. Appl Organometal Chem, 2014, 28: 113

[48] Byun E, Hong B, De Castro K A, Lim M, Rhee H. J Org Chem, 2007, 72: 9815 